\title{
Linking Local Appreciation with Conservation of an Edible Fruit Species: The Case Study of Ilama (Annona diversifolia Saff.) in Tierra Caliente, Mexico
}

\author{
Caroline Lefebvre ${ }^{1}$, Sergio Segura ${ }^{2 *}$, Alma Carmona ${ }^{3}$, Catherine Mathuriau ${ }^{4}$, Santiago Barrios $^{3}$, \\ Jorge Andrés ${ }^{2}$, Josué Medellín-Azuara ${ }^{5}$ \\ ${ }^{1}$ Institut National d'Horticulture, Angers, France \\ ${ }^{2}$ Centro Regional Universitario Centro Occidente, Universidad Autónoma Chapingo, Morelia, México \\ ${ }^{3}$ Facultad Ciencias Químico-Biológicas, Universidad Autónoma de Guerrero, Chilpancingo, Mexico \\ ${ }^{4}$ Centro del Cambio Global y la Sustentabilidad A.C., Villahermosa, Mexico \\ ${ }^{5}$ University of California, Merced, CA, USA \\ Email: *ssegura@correo.chapingo.mx
}

How to cite this paper: Lefebvre, C., Segura, S., Carmona, A., Mathuriau, C., Barrios, S., Andrés, J. and Medellín-Azuara, J. (2018) Linking Local Appreciation with Conservation of an Edible Fruit Species: The Case Study of Ilama (Annona diversifolia Saff.) in Tierra Caliente, Mexico. Natural Resources, 9, 337-353.

https://doi.org/10.4236/nr.2018.910021

Received: September 13, 2018

Accepted: October 19, 2018

Published: October 22, 2018

Copyright $\odot 2018$ by authors and Scientific Research Publishing Inc. This work is licensed under the Creative Commons Attribution International License (CC BY 4.0).

http://creativecommons.org/licenses/by/4.0/

\section{(c) (i) Open Access}

\begin{abstract}
The ilama tree (Annona diversifolia Saff.) is an underutilized fruit species from Mesoamerica with a noteworthy variability in southern Mexico. The present study describes differences in knowledge and appreciation of the fruit among inhabitants from different communities in Southern Mexico, as well as differences among their ilama trees. The study took place in Tierra Caliente, a region located in the states of Guerrero and the State of Mexico. Interviews were administered in three different communities as an attempt to associate the natural morphologic variation of plants and locals' knowledge and use of the tree in order to identify their implications for conservation. Data were analyzed by multivariate analysis, and the results suggest that the morphological variation of the plants and the commercial importance of ilama are well known by locals. Indigenous community inhabitants prefer and select only white pulp trees, whereas mestizo communities promote and conserve plants with white, red, purple, and blue pulp. Germplasm flow is dynamic in the region, and ilama fruit represents a different economic value for each community. Selling the fruit is the primary goal, but not specifically its conservation and promotion. Implications for in situ conservation of ilama in Mexico are discussed.
\end{abstract}

\section{Keywords}

Annona, Genetic Resources, In Situ Conservation, Mexico, 
Underutilized Species

\section{Introduction}

Commonly called ilama or ilama tree, Annona diversifolia Saff. is a Mesoamerican underutilized tree species producing an edible fruit. The species presents important morphological variation [1]. In Nahuatl language, ilama means "old woman's fruit". Its distribution encompasses the southern dry tropical region from Mexico to El Salvador [2] [3]. In Mexico, the distribution of ilama includes the states of Guerrero, Colima, Oaxaca, Chiapas, State of Mexico, Veracruz, and Michoacán [1] [2]. The Tierra Caliente region (Spanish for "Hot Land"), comprising the State of Mexico, Guerrero, and Michoacán contains the largest metapopulation of the ilama species [4]. Ilama trees grow from 6 to $8 \mathrm{~m}$ in height, even in poor soils of foothills in hot sub-humid climate regions. The tree produces a palatable and succulent fruit at the end of the winter. The fruit pulp is eaten fresh or made into chilled drinks and sherbets. It is sometimes served with a little cream and/or sugar to intensify the flavor [5]. The species grows in lowland and midland rainforest areas as an ephemeral tree. It is known for its tolerance to dry conditions [6]. Although the price of the ilama fruit is relatively high in local markets (0.5 - 1.5 USD each) and it represents a significant share of the income of many families in the region, its exploitation is still a marginal activity [3] [4].

The fruit is conical, and heart-shaped; it has an ovoid or globose structure. It is about $15 \mathrm{~cm}$ long and may weigh up to $1 \mathrm{~kg}$. Generally, the fruit is studded with more or less pronounced, and triangular protuberances, although fruits on the same tree may vary from rough to fairly smooth [5]. Morphological variations of ilama have been reported by [3] [4] [6]; all of these studies have focused on the Mexican region of Tierra Caliente. This southern region of Mexico is considered to host the largest metapopulation of ilama, most of it in the states of Guerrero and Mexico [1]. Differences between vegetative structures as size of the tree, growth habits, color and shape of leaves are described in the literature; five types of fruit pulp have been reported in the Tierra Caliente region: fruits with white, pink, red, purple, and blue pulp [6]. A. diversifolia is considered an important source of fiber, sugars, potassium, zinc, and biologically active components with antioxidant activity, such as flavonoids [7]. Industrial uses in biodiesel production and pharmaceutical applications have been studied by [8] [9] and [10].

The present study sought to understand the motivations of the different communities where this species is present in the Tierra Caliente region to preserve ilama trees. Although plant variations have been well described by previous studies, the human factors involved in its propagation and conservation are not yet well known. The link between the morphological variability of the 
ilama tree and human factors associated with culture, crop management, and the market might have an influence on the recognition of the value of ilama production.

\section{Material and Methods}

\subsection{Region of Study}

Three different communities in Tierra Caliente were selected for the study (Figure 1). In this part of southern Mexico, mestizo and indigenous communities are established in a territory that consists of low-elevation areas which, as the name suggests, are characterized by a hot climate. Overall precipitation is around $600 \mathrm{~mm} /$ year.

\subsection{Interviews with Inhabitants}

A semi-structured interview based on [11] was administered to inhabitants from each community. Interview questions were organized around seven themes regarding ilama management (Table 2). Answers to the questions were open, and non-technical language was used as recommended [12] and [13]. The questions encompassed a variety of topics including the inhabitant's knowledge about ilama development, tree count, locations of trees, uses of the ilama tree and its fruits, ways of extending the spatial coverage of ilama trees, and fruit commercialization. In addition to the information concerning ilama, we registered other data such as the age of the informant and household information, including the number of family members. A list of the information analyzed in the study is presented in Table 1.

Interviewees were chosen randomly, and sample sizes were proportional to the sizes of the communities. After having conducted a preliminary visit, we prepared a map of the villages including main streets and the distribution of

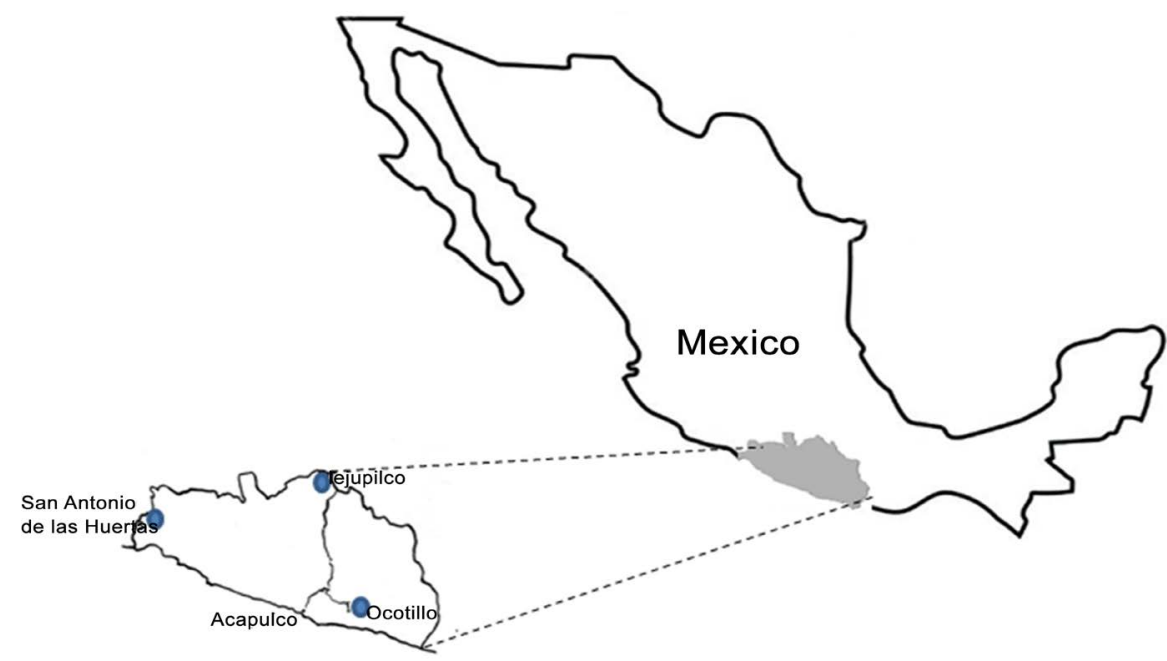

Figure 1. Localization of the three different communities studied in the Tierra Caliente region, Mexico. 
Table 1. Variables included in the study.

\begin{tabular}{|c|c|c|}
\hline Variable & Code & Unit \\
\hline Age of interviewee & EDAD & Years \\
\hline \multicolumn{3}{|l|}{ Knowledge about ilama and the property of the informant } \\
\hline Types of ilama known by interviewee & TYP & Unit \\
\hline Preferred type of ilama & GST & Categories \\
\hline Quantity of ilama trees visited & $\mathrm{ARB}$ & Unit \\
\hline Place where ilama trees are located into community & HRT & Categories \\
\hline Stomach ache due to fruit consumption & DAN & Yes/no \\
\hline \multicolumn{3}{|l|}{ Uses of ilama tree } \\
\hline Parts of the tree used & USO & Categories \\
\hline Medicinal use & MED & Yes/no \\
\hline Mode of the fruit consumption & PRP & Yes/no \\
\hline \multicolumn{3}{|l|}{ Fruit harvesting } \\
\hline Harvesting period & $\cos$ & Month \\
\hline Regularity of harvest season & TMP & Yes/no \\
\hline Criteria for harvesting fruits & CRT & Categories \\
\hline Fruit pulp texture preferred & CL1 & Categories \\
\hline Fruit pulp color preferred & CL2 & Categories \\
\hline \multicolumn{3}{|l|}{ Propagation of the tree } \\
\hline Ilama trees propagation & SMB & Yes/no \\
\hline Type of propagation & MOD & Categories \\
\hline Seed selection & SEL & Yes/no \\
\hline Other criteria to select ilama fruit & PR1 & Categories \\
\hline Introduction of plant material & OTR & Yes/no \\
\hline \multicolumn{3}{|l|}{$\underline{\text { Pests and diseases }}$} \\
\hline Knowledge of pests and diseases & ENF & Yes/no \\
\hline Presence of diseases & HNG & Yes/no \\
\hline Presence of pests & PLG & Yes/no \\
\hline Other putrefaction & PDR & Yes/no \\
\hline Pest control & CUR & Yes/no \\
\hline Diseases or pest resistance observed & SIN & Yes/no \\
\hline \multicolumn{3}{|l|}{$\underline{\text { Management of ilama trees }}$} \\
\hline Age of interviewee's trees & EDA & Years \\
\hline Quantity of fruits harvested & FRT & Unity \\
\hline Presence of unproductive trees & NOP & Yes/no \\
\hline Remotion of unproductive trees & FUT & Categories \\
\hline Growth habits & CUL & Categories \\
\hline Agricultural labors & $\mathrm{LAB}$ & Categories \\
\hline Use of chemical products & QUI & Categories \\
\hline Intention to plant ilama trees & MAS & Yes/no \\
\hline Preferred fruit pulp color preferred & CL2 & Categories \\
\hline
\end{tabular}




\begin{tabular}{ccc}
$\begin{array}{c}\text { Other criteria to plant ilama trees } \\
\text { Commercialization }\end{array}$ & PR2 & Categories \\
$\begin{array}{c}\text { Quantity of Ilama fruit sell outside } \\
\text { Fruit price in market }\end{array}$ & COM & Categories \\
Price received by the interviewee & MER & Peso or DLS \\
Type of ilama preferred by buyers & CMP & Peso and DLS \\
\hline
\end{tabular}

houses and other buildings. Authorities, teachers, and priests helped us to establish contact and rapport with the inhabitants. We found that the sample size of our data collection was governed by the law of diminishing returns noted by [12], which indicates that the amount of new information decline after a turnover point reached as sample size increases, that is to say, that we did not obtain more different information and thus, a total of 36 inhabitants were interviewed in San Antonio de las Huertas, 87 inhabitants in Tejupilco, and 18 in El Ocotillo.

\subsection{Information Analysis}

Data variables were analyzed using a non-parametric Spearman test of correlations followed by Multiple Correspondence Analysis (MCA), a multivariate technique. This analysis was used to find possible relationships among the variables in Table 2, which represent individual characteristics of interviewees; thus, differences among individuals and communities can be described, as recommended by [11] and [12]. The selected variables included information such as knowledge of the people about ilama, uses of the tree, and management and commercialization of the fruit. A matrix of 39 answers or variables in columns and people in lines was constructed. Relationships among variables helped to understand their descriptive capacity and similarities between individuals. Factorial plans obtained by MCA revealed the association between in situ approaches to crop management and appreciation of ilama fruit into and among communities.

\section{Results and Discussion}

As noted by [4], the natural spatial distribution of ilama in Mexico corresponds to the southern states of Guerrero, Oaxaca, Michoacán, State of Mexico, and Chiapas. The Tierra Caliente region in the states of Guerrero and Mexico, where the present study was conducted, presents the largest metapopulation of ilama in the country, as shown by [1]. Table 2 presents a description of the three communities where inhabitants were interviewed.

Recent research reports on Ilama have revealed important morphological variation among ilama populations in Tierra Caliente; this information was used as the basis for our own study: Important morphological variation is reported by [6] near to San Antonio de las Huertas producing fruits with blue, white, pink, and red pulp; similarly [3], studying a population of ilama in Tejupilco, found 
Table 2. Main characteristics of the three Tierra Caliente communities studied.

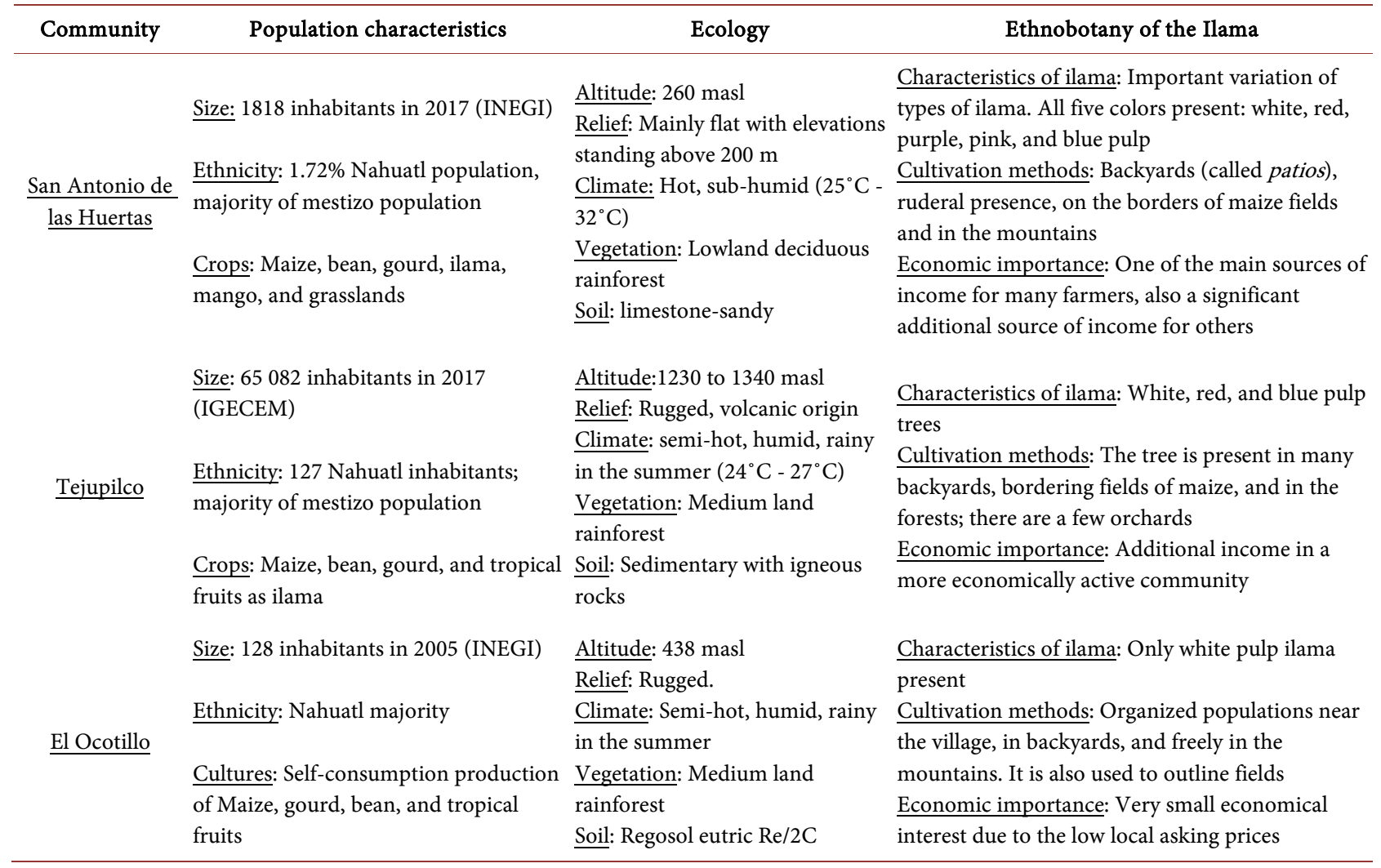

less morphological variation, but again, fruits with blue, white, pink, and red pulp; [14] studied ilama in the community of El Ocotillo reported populations of white-pulp ilama trees along the outline of the village (Figure 2).

Table 3 shows a Spearman correlation matrix for variables. In general, there are two kinds of landscape where ilama grows: the single-species-landscape and the multi-species-landscape. Important relationships among variables are, for instance, SMB (ilama tree propagation) and SEL (seed selection), which means that most interviewees would select seeds based on the fruit's attributes. CL1 and SEL were highly correlated as a result of the fact that the selection of the color of the fruit pulp is associated with its seeds (SEL). The habit of growing ilama trees (CUL) is also well correlated with the place where ilama trees are located (HRT). There are two kinds growing conditions: in the mountains or in backyards ( $p a-$ tios). Commercialization (COM) is highly correlated with the level of care given by the inhabitants to three. CUR (pest control) is also highly correlated with quantity of fruit harvested (FRT). Purple-pulp fruits are sold at a higher price in the market because their appearance is more attractive.

The data matrix included 71 individuals and 41 variables, which were analyzed by MCA. This analysis was employed to interpret variations among informants and their relationships with measured characteristics. The following sections describe the main results of MCA for each Community, an overall analysis including the three communities, and the implications for in situ conservation. 


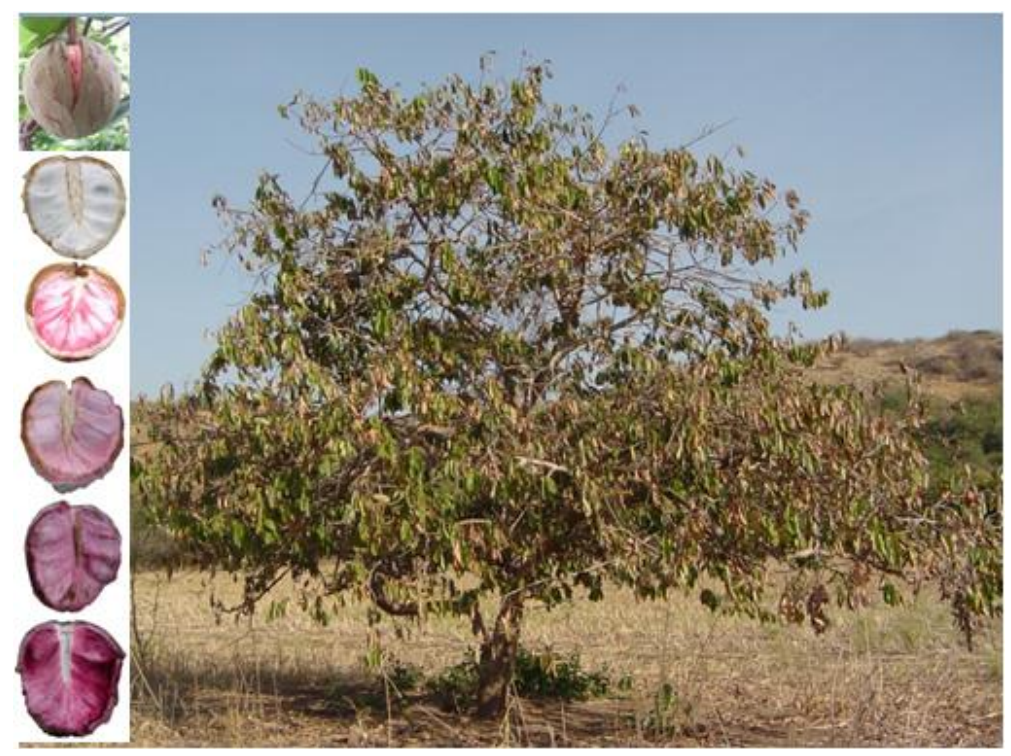

Figure 2. Ilama tree (Annona diversifolia Saff.) and fruit pulp variation in Tierra Caliente region, Mexico.

Table 3. Spearman's $\rho$ nonparametric correlations among variables studied. Codes according to Table 1 .

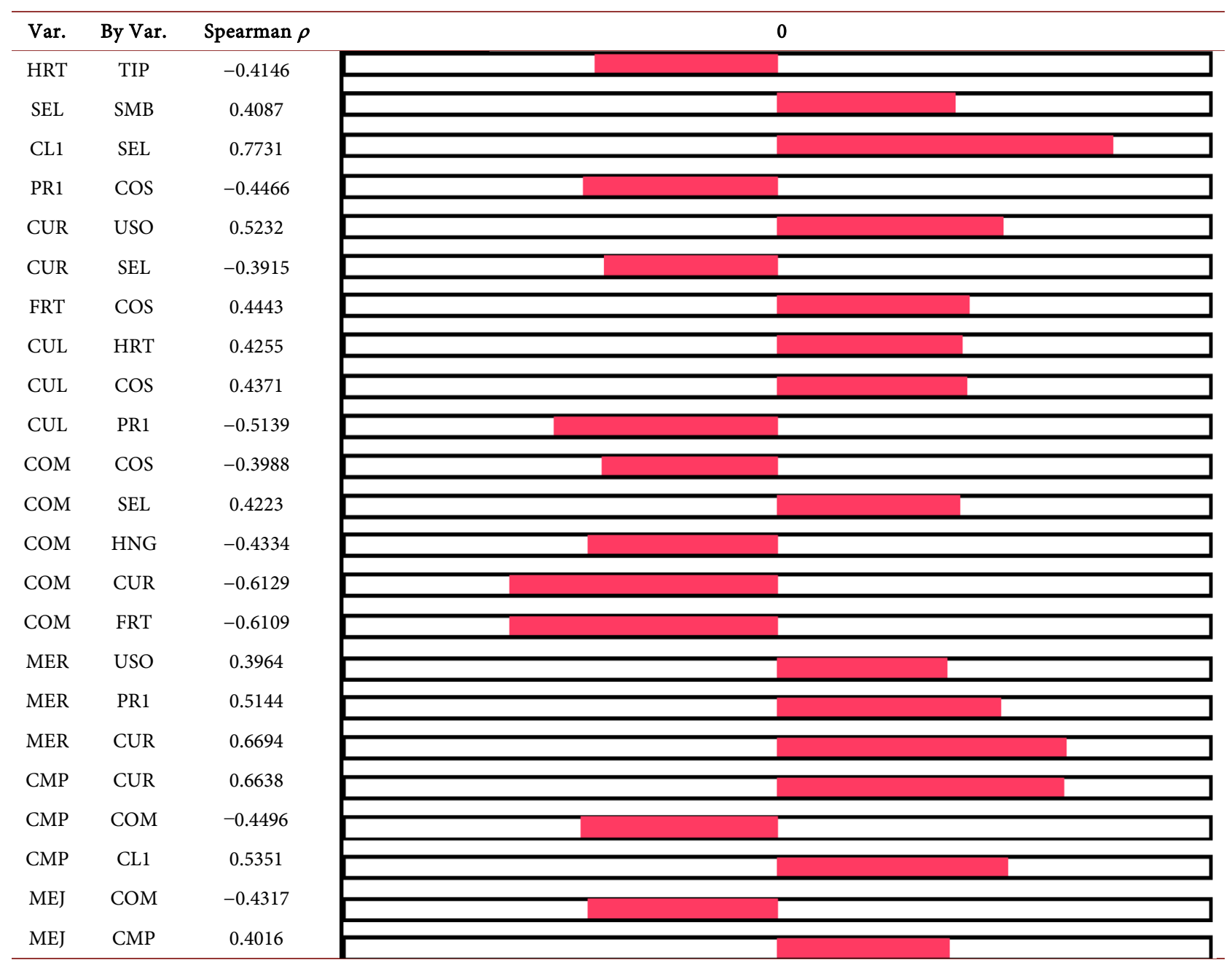




\subsection{San Antonio de Las Huertas}

In the community of San Antonio de Las Huertas, all the interviewees trade with the fruit during the harvest season (Figure 3). It represents an important source of income for many inhabitants, for example, DD or JC, who devote an important part of their time to harvest the fruits. During the harvest season, from $\mathrm{Au}$ gust to October, people go to the mountains to pick up the ilama in their small allotments. DD spends the night in the mountain during this period to protect his trees from thieves.

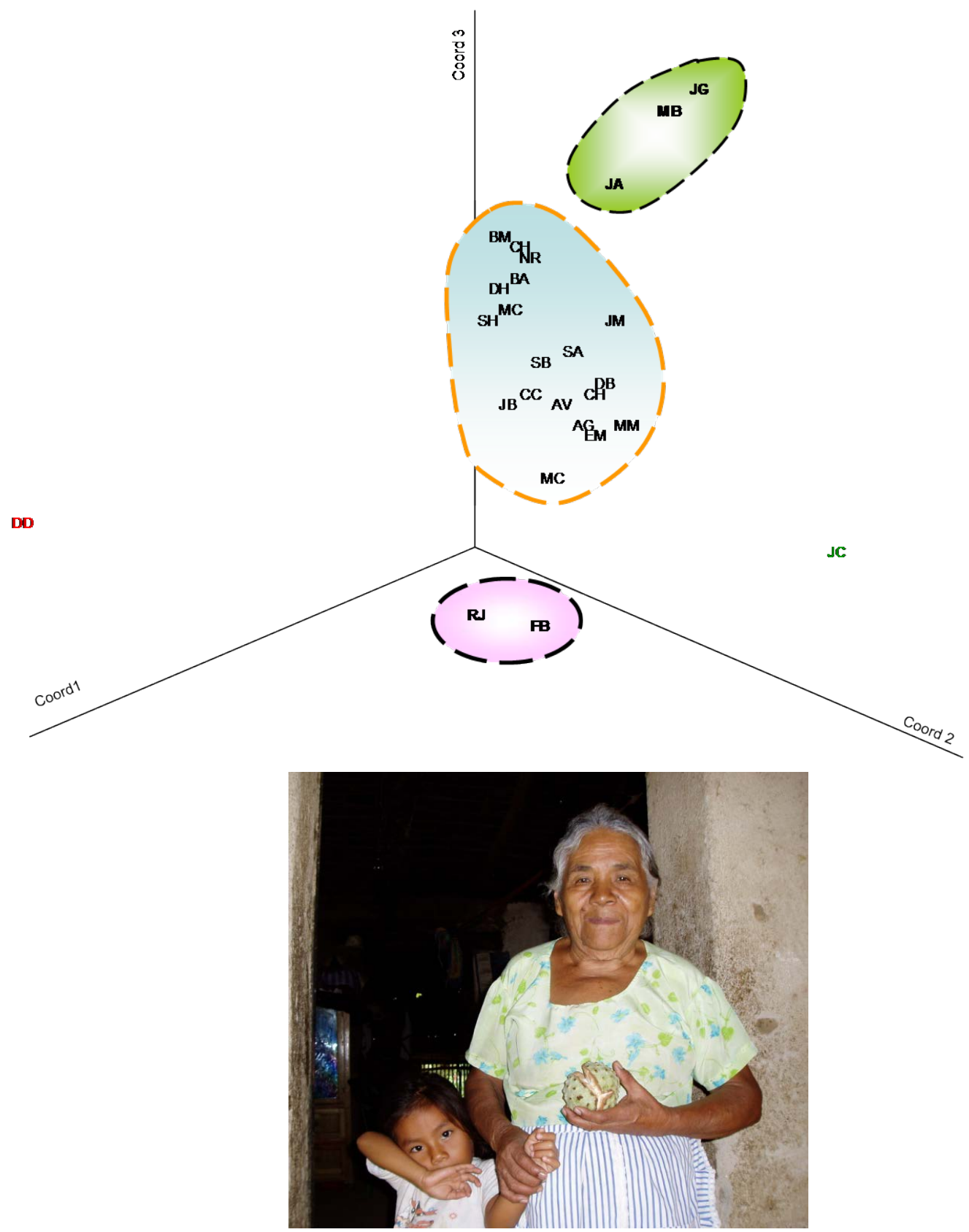

Figure 3. Informants distribution of San Antonio de la Huertas Community into the three principal factors of the MCA. Names of informants are noted by acronyms. More information in text. 
In this community, ilama crop management is more complicated than in the other studied communities. Farmers tidy out their orchard and sometimes use chemical products to prevent pests or diseases. Ilama is generally grown as a single crop, and selected seeds are used for propagation. San Antonio de Las Huertas is known for its wide diversity of ilama types, but the purple-pulp type is still the most appreciated, and the most expensive. The prices of the fruit in the marketplaces of Tlapehuala or Altamirano are very high, as noted [6]: around 1 USD a piece, and the farmers' profits are significant because they usually sell the fruits themselves. Among other interviewees, RJ and FB were aware of the weakness of the ilama market, and they were aware that the high price of the ilama fruit could drop rapidly in the event of an overproduction. Accordingly, they advise against planting more trees to avoid glutting the local market. RJ and $\mathrm{FB}$, now retired, owned 60 trees each and were very interested in discussing ilama crop management. The group of interviewees formed by MB, JG, and JA represents small owners. They have a dozen trees in the mountains, including white and purple pulp varieties. They do not use any chemicals or do any work in the fields. [1] reports that ilama fruit sales are a complementary source of income for the inhabitants of this region.

\subsection{Tejupilco}

Tejupilco is located in the mountains, and many backyards of houses in the village are planted with ilama trees and other edible fruit species like mango, lime, orange, tamarind, coffee, papaya, guava and greengage; ilama trees are also located into the maize fields (milpas) or used as natural barriers of the property's limits. In this region [3] point out that ilama trees produce up to 100 fruits per plant, and that the trees are especially vigorous, which be explained by the presence of favorable rainfall and temperature patterns in the area. Ilama trees are not maintained by the farmers except for annual cleaning of the orchard. The current price of ilama fruit is generally high because there are no agents mediating sales between farmers and the final consumer. People sell their fruits at prices ranging from 10 to 15 Mexican pesos (MXN) (0.5 to 0.75 USD). In Tejupilco, ilama fruits sell easily. A number of interviewees expressed peculiarities in their general perspective of ilama management; according to two farmers (LJ and SA), an excellent seed selection (from the largest and fleshiest fruits) and minimal tree management allowed them to harvest up to 200 fruits per tree in only one season (Figure 4). The responses of ES set him apart from the primary cluster of points in Figure 2, highlighting the unusual nature of his case; the person was from the community of Las Mesas, where a wild type named "Ilama zorro" (Annona sp.) can also be found. This interviewee was 65 years old at the time of the interview, and his harvest period is at the end of the season (October) because his trees are situated at 1200 masl. DJ and EJ are father and son, and they provided very similar answers. The son knows more about the purple ilama and would like to plant more of these trees. Their ilama trees are more than 50 years old, their heights are impressive, and they have an abundant production. 

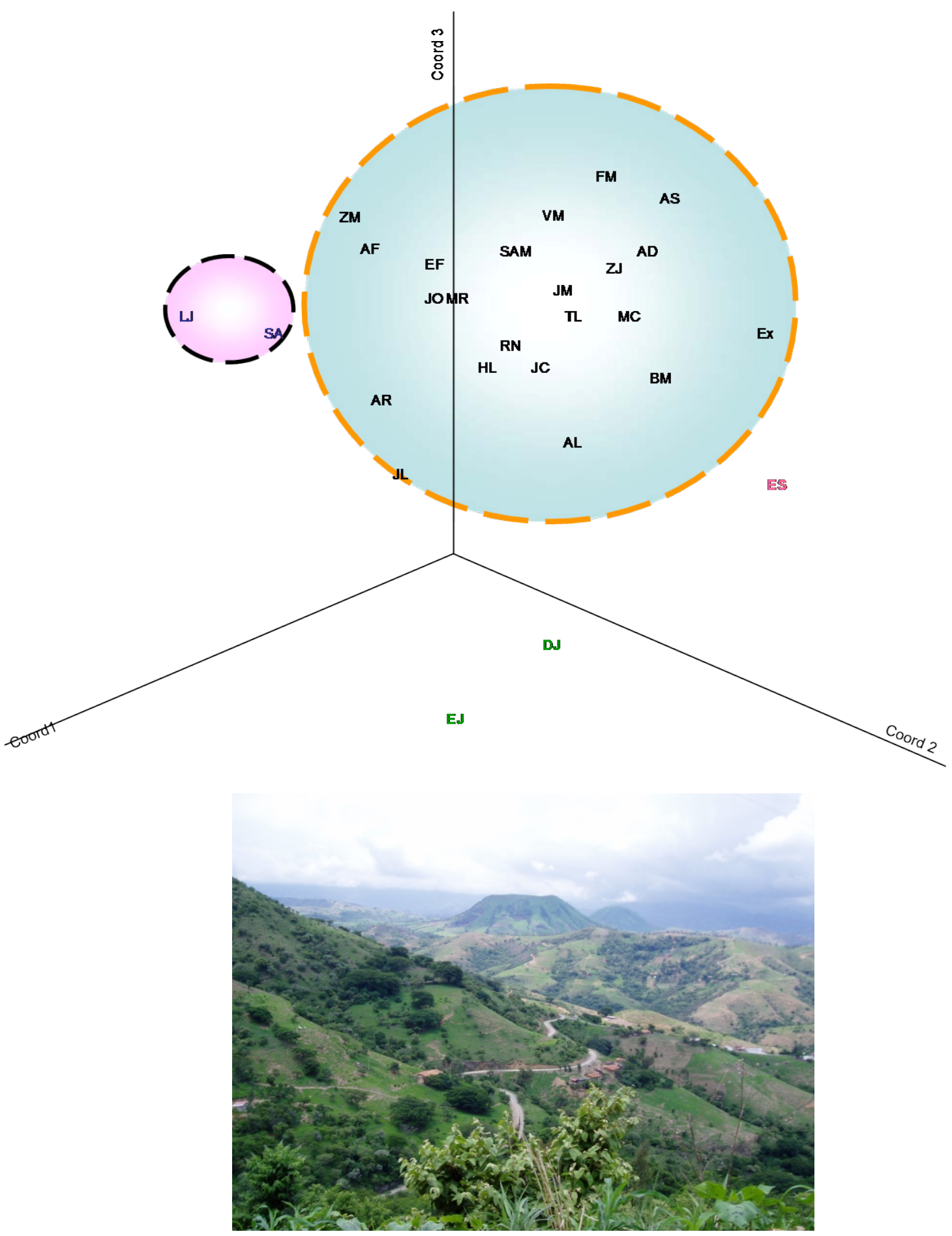

Figure 4. Informants distribution of Tejupilco Community into the three principal factors of the MCA. Names of informants are noted by acronyms. More information in text.

\subsection{El Ocotillo}

Inhabitants of El Ocotillo are less concerned about their ilama trees than people in other communities. Few of them harvest ilama fruits to sell them because it does not represent an important source of income. The white-pulp variety is the 
most common, but a few inhabitants have been sowing purple-pulp ilama for some years. The principal source of income of the community is the sales of gourd seed because their profits from this activity are greater than their profits from ilama fruit sales (around $2 \mathrm{MXN}$, or 0.1 USD a piece). Furthermore, the community is far from the municipality of San Marcos, which entails high transportation costs to be invested before selling the fruits in San Marcos city. Therefore, since market prices in the Costa Chica are very low, from 5 to $8 \mathrm{MXN}$ a piece (0.25 - $0.40 \mathrm{USD})$, and bringing the products to the city is complicated [14], the business is inviable. The branches of ilama trees in this community are also used as a support for wooden frames on which tiles are placed to build roofs. According to the inhabitants of the Ocotillo, the branches must be pruned under a full moon to obtain the best wood quality if this procedure is used, they can endure for three years. As can be observed in Figure 3, some individuals are placed outside the central cluster of points; it is the case of interviewee ES, who uses a more developed system to manage his trees. ES and his family planted purple-pulp ilama trees and sell the fruits in different local marketplaces. Contrary to the previous interviewee, RC and EC do not have their own trees but trade with fruits (Figure 5). They harvest ilama fruits freely in the mountains for their own consumption and occasionally sell a few kilos when there are plenty of fruits. These interviewees were two women of 75 and 35 years of age whose husbands had left Ocotillo to migrate to the USA. This fact can explain why RC and EC do not have any other economic activity. AE appears out of the cluster because of his particular selection of ilama propagation materials. AE selects seeds of two different kinds of ilama, the purple-pulp type, which sells better in the local marketplace, and the white-pulp type, which he prefers. He carefully selected seeds from the biggest, sweetest, and juiciest fruits of each type. Individual IM declared that he was introducing red-pulp ilama in Ocotillo by planting it in the mountains. Some interviewees indicated that the red-pulp ilama comes from the village of Tierra Colorada, approximately $100 \mathrm{~km}$ away from Ocotillo. Interesting if as noted [7], the sweetness of ilama fruit pulp is attributed mainly to sucrose and fructose; these represent $51.0 \%-55.3 \%$ and $24.5 \%-27.5 \%$, respectively, of the total sugars in the fruit, and the color of the pulp is associated with sweetness, for example, deep pink pulp is sweeter than white pulp, which means that this characteristic is important for the inhabitants of El Ocotillo.

\subsection{Joint Analysis of Communities}

Using data from the three communities, a conjoint MCA analysis produced Figure 6 and Table 4. The three observed groups of individuals are linked to the studied communities. In the first group, noted as A, the majority of individuals are from San Antonio de Las Huertas, they commercialize the fruits, and have a marked desire to propagate ilama. Inhabitants of this community tend their trees in the mountains. The commercialization of ilama represents an important part of family income in this community because market prices are high. On the other hand, El Ocotillo is the smallest community and its inhabitants are predominantly 


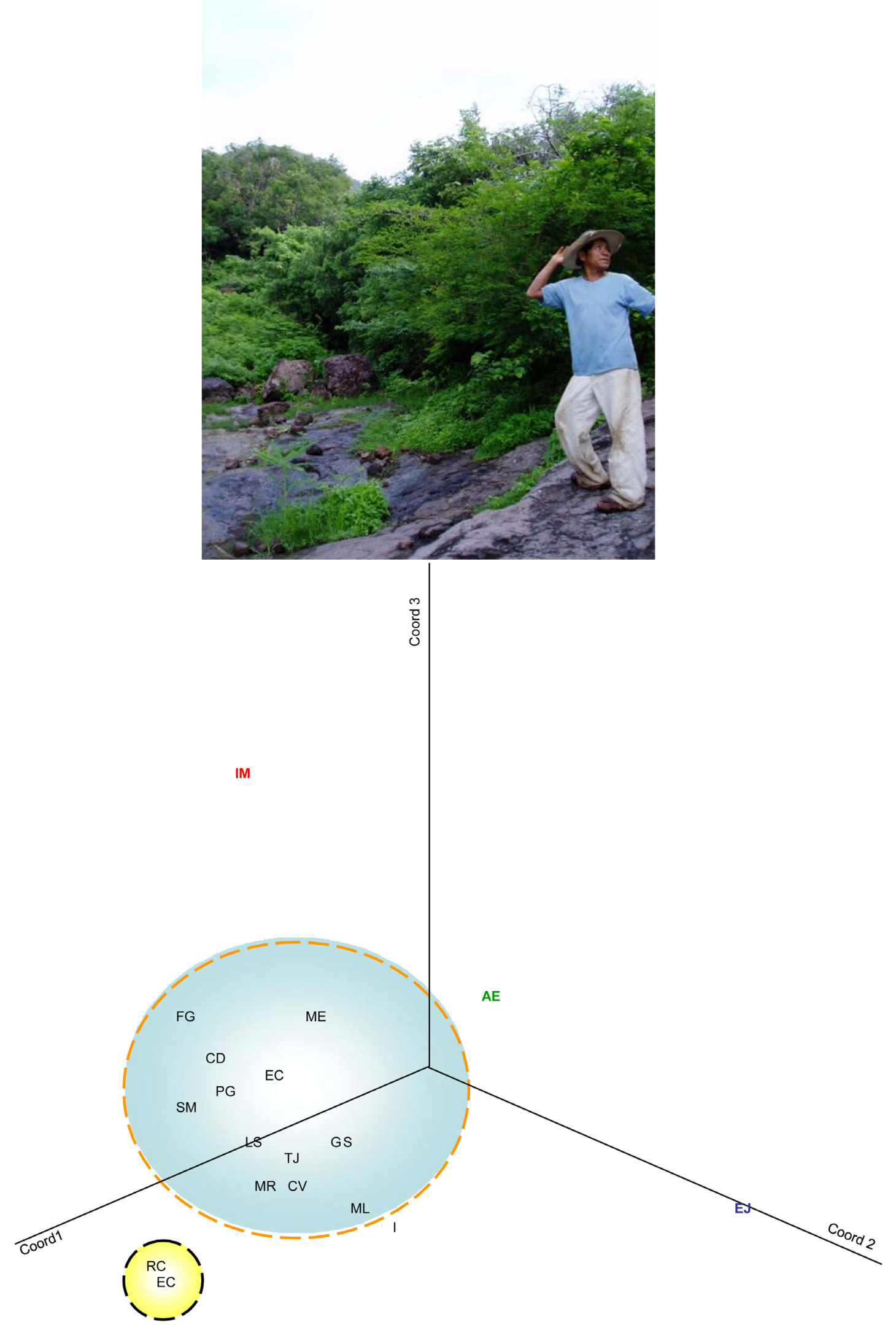

Figure 5. Informants distribution of El Ocotillo Community into the three principal factors of the MCA. Names of informants are noted by acronyms. More information in text. 


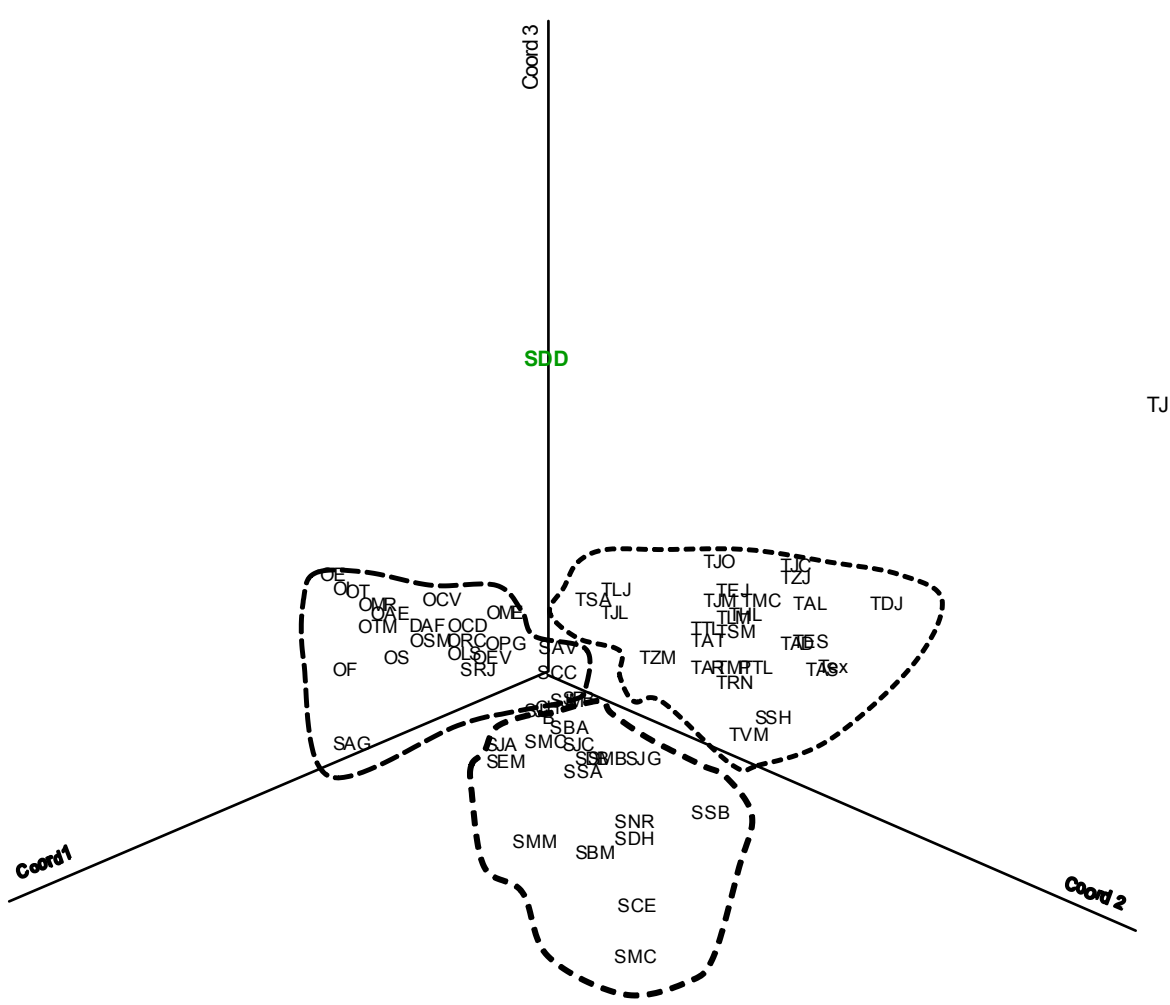

Figure 6. Informants distribution from the three communities studied into the three first factors of the MCA. First letter indicate the locality origin: $\mathrm{T}=$ Tejupilco; $\mathrm{S}=$ San Antonio de las Huertas; $\mathrm{O}=$ Ocotillo, the next two letters are the acronyms of their names. More information in text.

Table 4. Factor Contributions into MCA throughout the three Southern Communities studied in the Tierra Caliente Region. Only important variable contributions into factors are noted.

\begin{tabular}{|c|c|c|c|c|c|}
\hline & Factor 1 & Factor 2 & Factor 3 & Factor 4 & Factor 5 \\
\hline GST & - & - & - & - & 6.5 \\
\hline ARB & 5.33 & - & 6.29 & 7.88 & 10.64 \\
\hline HRT & 4.6 & - & - & - & - \\
\hline $\cos$ & 5.93 & - & - & - & - \\
\hline MOD & - & - & 6.65 & - & - \\
\hline SEL & - & 5.9 & - & - & - \\
\hline CL1 & - & 8.45 & - & - & - \\
\hline PR1 & 6.75 & - & - & 5.79 & - \\
\hline SIN & - & - & 6.88 & 5.48 & 12.29 \\
\hline EDA & - & 5.14 & 14.69 & 8.73 & - \\
\hline FRT & 5.09 & 4.96 & - & 5.19 & - \\
\hline CUL & 6.25 & - & - & - & - \\
\hline QUI & - & - & 11.32 & - & - \\
\hline $\mathrm{CO} 2$ & - & - & - & - & 6.04 \\
\hline PR2 & - & - & - & - & 6.09 \\
\hline
\end{tabular}


Continued

\begin{tabular}{cccccc}
\hline COM & - & 9.19 & - & - & - \\
MER & - & 11 & - & - & - \\
CMP & - & 8.63 & - & - & - \\
MEJ & 8.52 & -- & 9.28 & 10.57 & 11.54 \\
\% of variability & 42.7 & 53.27 & 55.11 & 43.64 & 64.93 \\
\hline
\end{tabular}

indigenous, but they have little interest in ilama. This group is closer to the first factor included in the MCA (Table 4), which represents an important number of trees, no orchard cultivation, and longer period of harvest. In fact, they possess numerous ilama trees in the mountains. People use the tree as a natural fence and harvest the fruit from mid-September to mid-October. The third group represents the community of Tejupilco, which has ambivalent attitudes toward ilama. Farmers place ilama trees in diverse places and use the fruits for different goals. They do not use any agronomic management method, but some farmers do not hesitate to use pesticides to guarantee a good yield (factor 3 in the MCA). Similar results are noted by [1] and [14]. The harvest period of ilama fruits is considered as late (September-October) and the fruit is readily sold in local marketplaces or on the roads around the center of the municipality (factor 2). The trees of this community are particularly old and vigorous, producing numerous fruits (factor 3).

\subsection{Implications for in Situ Conservation}

The appreciation of the value of ilama trees and their management by each community are directly related to their conservation and agronomic attention. The three studied communities reveled to have different mindsets about the selection of ilama trees in their landscape. As [3] and [1] [14], we observed that the inhabitants of this Mexican region acknowledge the commercial and biological value of the plant, which could increase small farmers' income. This edible fruit species is not yet actively cultivated in none of the three communities. As noted [13], it is possible to cultivate this underutilized species using a mono-crop orchard system, but this is not absolutely necessary. Our recommendation, opposed to [1], would entail no modification to current tree management systems except for pruning the trees and other minor agronomic interventions such as eliminating sick fruits at the end of the harvest season and possibly applying $\mathrm{Cu}$ to prevent fungal diseases. This remains a challenge to our current agronomic vision of fruticulture avoiding genetic drift as also noted [15] in Sudan. Different authors are studying medicinal properties of ilama [9] [16]; [5] has compiled the most relevant. This is another way to valorize the genetic resources of the species as well as a possible raw material source for biodiesel production [7] [10]. In any case, the promotion of ilama production needs to take into account different aspects of the human communities settled in the Tierra Caliente region, such as their culture, climate, and socioeconomic status. According to observations by 
[17] and [18], one of the current barriers to promote the commercial or semi-commercial exploitation of ilama is the natural conditions of the region, especially its low rainfall pattern (less than $700.1 \mathrm{~mm}$ per year). From the cultural perspective, we noted that all three communities are engaged in traditional backyard agriculture practices, mainly for self-sustenance as noted [19] from prehispanic times. Fortunately, people are already preserving the morphological variation of this species in situ due to its value as an edible fruit [13] and medicinal properties [20]. Nevertheless, urban pressure as shows [15], the inclination to opt for commercial agriculture, and illegal harvesting by outsiders are factors that were not included in the present study.

\section{Conclusion}

Three different communities in the southern Mexican region called Tierra Caliente, in the states of Guerrero and the State of Mexico, were studied to describe the possible links between the natural variation of ilama trees and inhabitants' appreciation of the commercial value of this species to identify implications for conservation. The focus of the study was on the fruit and local people's knowledge about the species. Interviewees were chosen randomly after a preliminary visit to the communities, and sample sizes were proportional to the size of the communities. A total of 36 inhabitants from San Antonio de las Huertas, 87 inhabitants from Tejupilco, and 18 from El Ocotillo were administered an interview. Collected data were analyzed using multivariate analysis and results suggested that the morphological variation of the plants and the commercial importance of ilama are well known by locals but not always well appreciated. Contrary to what was expected, inhabitants from the indigenous community of El Ocotillo, prefer and select only white-pulp plants, whereas the mestizo communities of Tejupilco and San Antonio de las Huertas, promote and conserve more variant populations of plants with white, red, purple, and blue pulp fruits. While germplasm interchange is dynamic in the region, the ilama fruit is given different appreciation by each community and although it is possible to cultivate this underutilized species using a mono-crop orchard system, this is not possibly necessary because it should bring a loss of the richness of types of fruits. We recommend then that current plant management systems remain unchanged, except for minor agronomic manipulations to the tree such as pruning and elimination of sick fruits.

\section{Acknowledgements}

The authors appreciate the economic support of the Annona Network of the Plant Genetic Resources National System (SINAREFI) of Mexico and the Autonomous University of Chapingo, as well as the valuable suggestions of Lila Marroquín and the kind availability of the inhabitants of the communities of El Ocotillo, San Antonio de las Huertas, and Tejupilco, Mexico. Special thanks to Dr. Paubelle and his Staff at the HCU/Lyon-Sud, France and the facilities of the 


\section{CRUCO-UACh in Mexico.}

\section{Conflicts of Interest}

The authors declare that they have no conflict of interest.

\section{References}

[1] Otero-Sánchez, M., Becerril-Román, A.E., Castillo-Morales, A., Michel-Aceves, A.C., Ariza-Flores, R., Barrios-Ayala, A. and Rebolledo-Martínez, A. (2006) Producción de ilama (Annona diversifolia Saff.) en el trópico seco de Guerrero, México. Revista Chapingo Serie Horticultura, 12, 137-143. https://doi.org/10.5154/r.rchsh.2005.09.035

[2] Popenoe, W. (1920) Manual of Tropical and Subtropical Fruits, excluding the Banana, Coconut, Pineapple, Citrus Fruits, Olive, and Fig. McMillan, New York, 474.

[3] Estrada, C.A. and Marroquín-Andrade, L.M. (1994) Caracterización de ilama (Annona diversifolia Saff.) en Salitre de Palmerillos, Amatepec, México. Proc. Interamer. Soc. Trop. Hort., 38, 197-200.

[4] Marroquín-Andrade, L., Cuevas, J., Guerra, D., Reyes, L., Reyes-Chumacero, A. and Reyes-Trejo, B. (2011) Proximate Composition, Mineral Nutrient and Fatty Acids of the Seed of Ilama, Annona diversifolia Saff. Scientific Research and Essays, 6 , 3089-3093.

[5] Lim, T.K. (2012) Annona diversifolia. In: Lim, T.K., Ed., Edible Medicinal and Non-Medicinal Plant, 1st Edition, Springer, Dordrecht, 176-179.

[6] Ballesteros-Patrón, G., Zavala-Hernández, F., Vergara-Hernández, R. and Cortés-Sarabia, J. (2015) Conservación, mejoramiento y fomento de la Ilama (Annona diversifolia Saff) en la tierra caliente del balsas. Foro de Estudios Sobre Guerrero, 1-2, 567-572.

[7] Julián-Loaeza, A.P., Santos-Sánchez, N.F., Valadez-Blanco, R., Sánchez-Guzmán, B.S. and Salas-Coronado, R. (2011) Chemical Composition, Color, and Antioxidant Activity of Three Varieties of Annona diversifolia Safford Fruits. Industrial Crops and Products, 34, 1262-1268. https://doi.org/10.1016/j.indcrop.2010.06.012

[8] Carballo, A., Martínez, A., González-Trujano, M., Pellicer, F., Ventura-Martínez, R., Díaz-Reval, M. and López-Muñoz, F. (2010) Antinociceptive Activity of Annona diversifolia Saff. Leaf Extracts and Palmitone as a Bioactive Compound. Pharmacology, Biochemistry and Behavior, 95, 6-12.

https://doi.org/10.1016/j.pbb.2009.11.017

[9] De la Cruz-Chacón, I. and González-Esquinca, A. (2013) Activities of Enzymes Catalyzing Benzylisoquinoline Alkaloid Biosynthesis in Annona diversifolia Saff. during Early Development. Russian Journal of Plant Physiology, 60, 791-799. https://doi.org/10.1134/S1021443713060034

[10] Reyes-Trejo, B., Guerra-Ramírez, D., Zuleta-Prada, H., Axayácatl Cuevas-Sánchez, J., Reyes, L., Reyes-Chumacero, A. and Rodríguez-Salazar, J. (2014) Annona diversifolia Seed Oil as a Promising Non-Edible Feedstock for Biodiesel Production. Industrial Crops and Products, 52, 400-444. https://doi.org/10.1016/j.indcrop.2013.11.005

[11] Kewessa, G., Amdie, T. and Demessie, A. (2015) Indigenous Knowledge on the Use and Management of Medicinal Trees and Shrubs in Dale District, Sidama Zone, Southern Ethiopia. Ethnobotany Research and Applications, 14, 171-182.

https://doi.org/10.17348/era.14.0.171-182 
[12] Begossi, A. (1996) Use of Ecological Methods in Ethnobotany: Diversity Indices. Economic Botany, 50, 280-289. https://doi.org/10.1007/BF02907333

[13] Gavin, M.C. and Gregory, J.A. (2005) Testing a Rapid Quantitative Ethnobotanical Technique: First Steps towards Developing a Critical Conservation Tool. Economic Botany, 59, 112-121. https://doi.org/10.1663/0013-0001(2005)059[0112:TARQET]2.0.CO;2

[14] Castañeda-Vildózola, A., Nava-Díaz, C., Váldez-Carrasco, J., Ruiz-Montiel, C., Vidal-Hernández, L. and Barrios-Matias, S. (2010) Distribution and Host Range of Bephratelloides cubensis Ashmead (Hymenoptera: Eurytomidae) in Mexico. Neotropical Entomology, 39, 1053-1055. https://doi.org/10.1590/S1519-566X2010000600034

[15] Thompson, J.L., Gebauer, J., Hammer, K. and Buerkert, A. (2010) The Structure of Urban and Peri-Urban Gardens in Khartoum, Sudan. Genetic Resources and Crop Evolution, 57, 487-500. https://doi.org/10.1007/s10722-009-9485-4

[16] Schlie-Guzmán, M., García-Carrancá, A. and Rosa González-Esquinca, A. (2009) In Vitro and in Vivo Antiproliferative Activity of Laherradurin and Cherimolin-2 of Annona diversifolia Saff. Phytotherapy Research: PTR, 23, 1128. https://doi.org/10.1002/ptr.2760

[17] Andrés-Agustín, J. and Andrés Hernández, L. (2011) Biología, diversidad, conservación y uso sostenible de los recursos genéticos de Annonaceae en México. Universidad Autónoma Chapingo-Centro Regional Universitario Centro Occidente. Chapingo, México, $141 \mathrm{p}$.

[18] Andrés-Agustín, J. and Segura-Ledesma, S.D. (2014) Conservation and Use of Genetic Resources of Annonaceae in Mexico. The Revista Brasileira de Fruticultura, 36, 118-124.

[19] Safford, W.E. (1912) Annona diversifolia, a Custard-Apple of the Aztecas. Journal of the Washington Academy of Sciences, 2, 118-125.

[20] López-Rubalcava, C. and Estrada-Camarena, E. (2016) Mexican Medicinal Plants with Anxiolytic or Antidepressant Activity: Focus on Preclinical Research. Journal of Ethnopharmacology, 186, 377-391. https://doi.org/10.1016/j.jep.2016.03.053 